\title{
PEMBUATAN BIOETANOL DARI RUMPUT GAJAH DENGAN PROSES HIDROLISIS ASAM
}

\author{
Netty Herawati ${ }^{1)^{*}}$, Kiagus Ahmad roni' ${ }^{2)}$, Sinta Fransiska ${ }^{2),}$ Rifdah $^{2)}$ \\ ${ }^{1}$ Program studi S3 Ilmu Teknik, Fakultas Teknik, Universitas Sriwijaya \\ ${ }^{2}$ Program studi Teknik Kimia, Fakultas Teknik, Universitas Muhammadiyah Palembang \\ *email: Nettyherawati76@gmail.com
}

\begin{abstract}
Abstrak
Bioetanol dapat dihasilkan dari tanaman yang banyak mengandung selulosa. Bioetanol adalah cairan biokimia yang didapat melalui proses fermentasi gula dari sumber karbohidrat (pati), selulosa dan glukosa menggunakan bantuan mikroorganisme. Salah satu sumber lignoselulosa yang ada di Indonesia adalah rumput gajah (pennisetum purpureum). Pembuatan bioetanol dari bahan-bahan lignoselulosa hingga menjadi etanol melalui proses utama: hidrolisa, fermentasi dan distilasi (pemurnian). Variabel yang digunakan dalam penelitian ini antara lain: proses pretretment $\mathrm{NaOH}$ konsentrasi 8, 10, 12, 14 dan $16 \%$, jenis asam saat hidrolisis yaitu Asam Sulfat dan Asam Klorida, konsetrasi asam: 1,5; 2; 2,5; 3; 3,5 $\mathrm{N}$ dan waktu hidrolisis 120, 150, 180, 210 dan 240 menit. Hasil terbaik dari penelitian ini yaitu menggunakan pretretment konsentrasi $\mathrm{NaOH} 14 \%$, hidrolisis asam klorida pada konsentrasi $3 \mathrm{~N}$ terhadap waktu 210 menit. Hasil HCL terbaik yaitu 90,5423\% yield. Sedangkan asam sulfat yaitu $77,9560 \%$ yield.
\end{abstract}

Kata Kunci : Rumput gajah, $\mathrm{NaOH}, \mathrm{H}_{2} \mathrm{SO}_{4}$, $\mathrm{HCL}$, bioethanol

\section{PENDAHULUAN}

Peningkatan jumlah populasi manusia seiring dengan meningkatnya pertumbuhan industri dan ekonomi di Indonesia dimana ketergantungan pemakaian bahan bakar minyak (BBM) semakin tinggi sedangkan cadangan sumber bahan bakar semakin menipis. Bioetanol merupakan sumber energi alternatif pengganti bahan bakar minyak yang ramah lingkungan dengan memiliki angka oktan yang lebih tinggi dari premium yaitu 115, premium 88 dan pertamax 98. Bioetanol dapat dihasilkan dari tanaman yang banyak mengandung selulosa. Bioetanol merupakan sumber energi yang dapat diperbaharui sehingga tidak perlu di khawatirkan lagi persediaan sumber energi di Indonesia akan semakin menipis. Bioetanol adalah cairan biokimia yang didapat melalui proses fermentasi gula dari sumber karbohidrat (pati), selulosa dan glukosa menggunakan bantuan mikroorganisme (Aryeni, dkk, 2017). Sebagai negara tropis, Indonesia memiliki sumber energi non fosil relatif sangat besar. Namun pemanfaatannya energi non fosil jauh lebih kecil dibandingkan dengan potensi yang ada. Salah satu energi alternatif yang berasal dari energi non fosil yang dapat diperbaharui adalah bioetanol. Salah satu sumber lignoselulosa yang ada di Indonesia adalah rumput gajah (pennisetum purpureum). Tanaman rumput gajah sangatlah banyak dan tersebar secara merata di seluruh pelosok tanah air dikarena iklim di Indonesia mempermudah tumbuhnya rumpu gajah, terutama di daerah Sumatera Selatan kota Palembang di daerah Jakabaring. Dimana ketersediaan rumput gajah dapat secara kontinyu melimpah. Rumput gajah 
merupakan salah satu tanaman yang kurang dimanfaatkan. Selama ini rumput hanya digunakan sebagai makanan ternak, bahkan masyarakat menganggap rumput gajah sebagai tanaman pengganggu. Tetapi rumput gajah mempunyai kadar selulosa tinggi (40,58 \%) yang dapat digunakan sebagai salah satu bahan penghasil bioetanol. Kandungan gizi rumput gajah yaitu bahan kering 19,9\%, protein kasar 10,2 \%, lemak 1,6 \%, serat kasar 34,2 \%, bahan esktrak tanpa nitrogen 42,3\% dan abu 11,7\%. Kandungan lain dari rumput gajah adalah : Glukosa : 2,84 \% ; Air : 43,61 \%. (Yuni Erlita, S.Pt. 2016). Penelitian ini meggunakan proses hidrolisis asam kuat dimana proses hidrolisis itu meliputi proses pemecahan ikatan lignin, menghilangkan kandungan lignin dan hemiselulosa, merusak struktur kristal dari selulosa serta meningkatkan porositas bahan. Rusaknya kristal selulosa akan mempermudah terurainya selulosa menjadi glukosa. Selain itu, hemiselulosa turut terurai menjadi gula sederhana, yaitu glukosa, galaktosa, manosa, heksosa, pentose, xilosa, dan arabinose. Selanjutnya senyawa-senyawa gula sederhana tersebut akan difermentasi oleh mikroorganisme menghasilkan etanol (Mosier et al., 2005).

\section{Rumput Gajah}

Rumput gajah (Pennisetum purpureum) merupakan tanaman bernutrisi tinggi yang hidup dengan tingkat curah hujan lebih kurang $2.500 \mathrm{ml}$. Dan tumbuh pada ketinggian 0-3000 m diatas permukaan laut dengan pH lebih kurang 6,5. Kondisi tanah yang diperlukan agar menghasilkan produksi rumput gajah yang optimal adalah memiliki kelembapan 60-70\%. Rumput gajah disebut juga naper atau rumput uganda adalah tegak lurus hingga tinggi batang dapat mencapai 2-6 meter, merumpun lebat, berbatang tebal dan keras dengan diameter batang dapat mencapai lebih dari $2 \mathrm{~cm}$, daun panjang seperti daun pada tanaman tebu dengan panjang mencapai lebih dari 1 meter dan terdiri sampai lebih dari 15 ruas/buku.
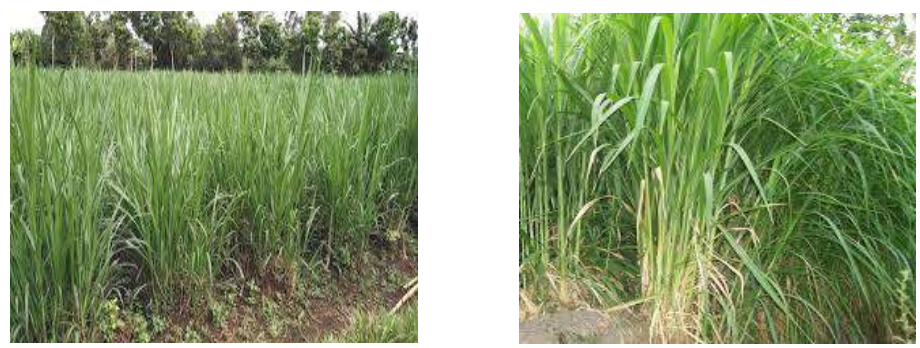

Gambar 1. Rumput Gajah

Komposisi nutrien rumput gajah dapat dilihat pada tabel 1

Tabel 1. Komposisi nutrien rumput gajah

\begin{tabular}{|c|c|}
\hline Komponen & $\mathrm{Kg}$ \\
\hline $\mathrm{N}$ (Nitrogen) & $10-30$ \\
\hline $\mathrm{P}$ (Protein) & $2-3$ \\
\hline $\mathrm{K}$ (Kalium) & 30 \\
\hline $\mathrm{Ca}$ (Kalsium) & $3-6$ \\
\hline $\mathrm{Mg}$ (Magnesium) & $2-3$ \\
\hline $\mathrm{S}$ (Sulfur) & $2-3$ \\
\hline
\end{tabular}

Sumber : (Rukmana, 2005). 


\section{Bioetanol}

Bioetanol $\left(\mathrm{C}_{2} \mathrm{H}_{5} \mathrm{OH}\right)$ adalah cairan biokimia hasil dari proses fermentasi gula dari karbohidrat (pati) dengan menggunakan mikroorganisme. Bioetanol yang dihasilkan dari bahan baku tanaman yang mengandung pati atau karbohidrat, dilakukan melalui proses konversi karbohidrat menjadi gula atau glukosa dengan beberapa metode salah satunya dengan metode hidrolisis asam dan secara enzimatis (Djojonegoro,W., (2005). Metode hidrolisis secara enzimatis lebih sering digunakan karena lebih ramah lingkungan dibandingkan dengan katalis asam. Glukosa yang diperoleh selanjutnya dilakukan proses fermentasi atau peragian dengan menambahkan yeast atau ragi. Bioetanol dapat dihasilkan dari macammacam tanaman yang banyak mengandung nira bergula (sukrosa) : nira tebu, nira nipah, nira sorgum manis, nira kelapa, nia aren, nira siwalan, sari nuah mete ; bahan berpati : tepung-tepung sorgum biji, sagu, singkong, ubi jalar, ganyong, garut, umbi dahlia ; bahan berselulosa (lignoselulosa) : kayu, jerami, batang pisang, bagas dan lain-lain.

Tabel 2. Sifat Kimia dan Fisik Bioetanol

\begin{tabular}{|l|l|l|l|}
\hline \multicolumn{2}{|c|}{ SIFAT KIMIA } & \multicolumn{2}{c|}{ SIFAT FISIK } \\
\hline Komponen & \multicolumn{1}{c|}{ Berat } & \multicolumn{1}{c|}{ Komponen } & \multicolumn{1}{c|}{ Berat } \\
\hline Karbon & 52,1 & Berat Molekul & $46,07 \mathrm{gr} / \mathrm{mol}$ \\
\hline Okdrogen & 13,1 & Densitas & $0,7894 \mathrm{gr} / \mathrm{cm}^{3}$ \\
\hline Karbongen & 34,7 & Titik didih & $78{ }^{\circ} \mathrm{C}$ \\
\hline Keperluan udara & 4,0 & Titik leleh & $-112^{\circ} \mathrm{C}$ \\
\hline & 9,0 & Titik nyata & $17{ }^{\circ} \mathrm{C}$ \\
\hline & & Indeks bias & 1,36014 \\
\hline
\end{tabular}

Sumber : Berdasarkan Lembar Data Keselamatan Bahan Menurut Peraturan UE No 1907/2006

\section{Pembuatan Bioetanol}

Pembuatan bioetanol dari bahan-bahan lignoselulosa hingga menjadi etanol melalui proses utama: hidrolisa, fermentasi dan terakhir adalah pemisahan serta pemurnian produk etanol (Mosier et al., 2005). Proses Pretreatment Proses pretreatment dan hidrolisa merupakan tahapan proses yang sangat penting yang dapat mempengaruhi perolehan yield etanol. Proses pretreatment dilakukan untuk mengkondisikan bahan-bahan lignosellulosa baik dari segi struktur dan ukuran. Proses perlakuan awal dilakukan karena beberapa faktor seperti kandungan lignin, ukuran partikel serta kemampuan hidrolisis dari selulosa dan hemiselulosa (Hendriks dan Zeeman, 2009). Proses pretreatment yang sekaligus proses hidrolisa meliputi : perlakuan secara fisik, fisik-kimiawi, kimiawi dan enzimatik (Mosier et al., 2005; Sun and Cheng, 2002). 
Tabel 3. Metode Pretreatment

\begin{tabular}{|l|l|}
\hline \multicolumn{1}{|c|}{ Metode Pretreatment } & Contoh \\
\hline Mekanik panas & Digerus, digiling, digunting, extruder \\
\hline Autohydrolysis & Super critical, carbon dioxide explotion \\
\hline Perlakuan asam & $\begin{array}{l}\text { Asam sulfat dan asam khlorida encer, asam sulfat } \\
\text { dan asam khlorida pekat }\end{array}$ \\
\hline Perlakuan alkali & $\begin{array}{l}\text { Sodium hidroksida, ammonia, alkali hydrogen } \\
\text { peroksida }\end{array}$ \\
\hline Perlakuan larutan organik & Methanol, etanol, butanol, phenol \\
\hline \multicolumn{2}{|c|}{ Sumber : Mosier et al., 2005; Sun and Cheng,2002 }
\end{tabular}

Tujuan dari pretreatment adalah untuk membuka struktur lignoselulosa agar selulosa menjadi lebih mudah diakses oleh enzim yang memecah polimer sakarida menjadi monomer gula. Pretreatment menyediakan akses yang lebih mudah untuk enzim sehingga akan mengalami peningkatan hasil glukosa dan xilosa (Isroi, dkk (2013). Tujuan pretreatment secara skematis ditunjukan oleh gambar dibawah ini.

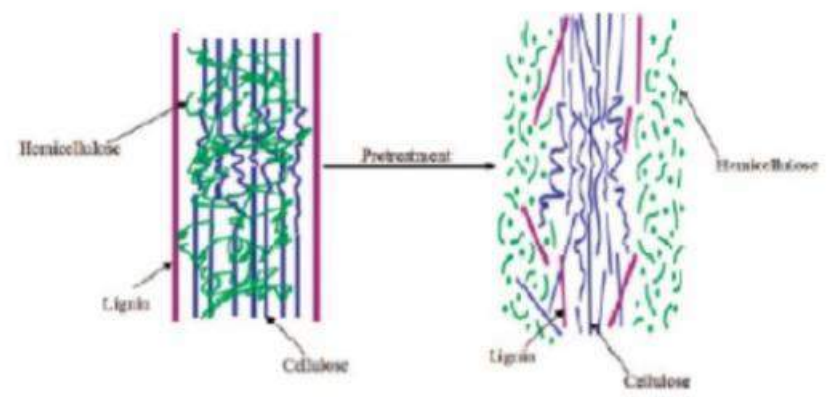

Gambar 2. Skematik dari proses perusakan struktur lignin (Kumar et al, 2009).

Selama beberapa tahun terakhir berbagai teknik pretreatment telah dipelajari melalui pendekatan biologi, fisika, kimia. Menurut (Sun dan Cheng, 2002), pretreatment seharusnya memenuhi kebutuhan berikut ini:

1) Meningkatkan pembentukan gula atau kemampuan menghasilkan gula pada proses berikutnya melalui hidrolisis enzimatik

2) Menghindari degradasi atau kehilangan karbohidrat

3) Menghindari pembentukan produk samping yang dapat menghambat proses hidrolisis dan fermentasi

4) Biaya yang dibutuhkan ekonomis

\section{Hidrolisis}

Hidrolisis adalah reaksi organik dan anorganik dimana terdapat pengaruh air terhadap dekomposisi ganda dengan komponen yang lain. Hidrolisis meliputi proses pemecehan ikatan lignin yang bertujuan menghilangkan kandungan lignin dan hemisellulosa, merusak struktur kristal sellulosa dan meningkatkan porositas bahan (Sun and Cheng, 2005).

Reaksi Hidrolisis:

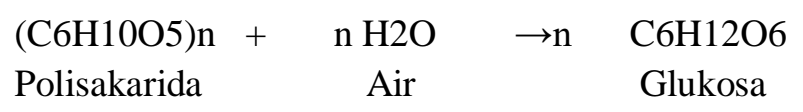


Reaksi antara air dan pati berlangsung sangat lambat sehingga diperlukan bantuan katalisator untuk memperbesar kereaktifan air. Katalisator asam yang biasa digunakan adalah asam klorida, asam nitrat dan asam sulfat. Sedangkan didalam industri, asam yang dipakai yaitu $\mathrm{H}_{2} \mathrm{SO}_{4}$ dan $\mathrm{HCl}$. Hidrolisis asam merupakan hidrolisis menggunkan asam yang dapat mengubah polisakarida (pati, selulosa) menjadi gula (Retno Dyah, 2011). Hidrolisi asam biasanya menggunakan asam klorida atau asam sulfat dengan konsentrasi tertentu. Hidrolisis secara asam dapat dilakukan drngan menggunakan asam kuat encer pada temperatur tinggi dan tekanan tinggi, dan dapat dilakukan dengan asam pekat dengan temperatur dan tekanan rendah. Proses hidrolisis yang terjadi pada suhu tinggi berkisaran pada suhu $160-240^{\circ} \mathrm{C}$, sedangkan pada suhu rendah berkisaran pada suhu $80-140^{\circ} \mathrm{C}$. Namun demikian, konsentrasi asam yang digunakan sangat tinggi $(30-70 \%)$. Hidrolisis asam encer biasa juga dikenal dengan hidrolisis asam dua tahap (Two Stage Acid Hidolysis) dan merupakan metode hidrolisis yang banyak berkembang dan diteliti saat ini. Hidrolisis asam encer pertama kali dipatenkan oleh H.K. Moore pada tahun 1919. Potongan (Chip) kayu dimasukan kedalam tanki kemudiaan diberikan uap panas pada suhu $300^{\circ} \mathrm{C}$ selama satu jam. Selanjutnya dihidrolisis dengan asam fosfat. Hidrolisis dilakukan dalam dua tahap. Hidrolisis yang dihasilkan kemudian difermentasi untuk menghasilkan etanol. Asam yang biasanya digunakan untuk hidrolisis selulosa adalah asam sulfat, asam fosfat dan asam klorida (Oktavianus, 2013). Hidrolisis menggunakan asam pekat menghasilkan gula yang tinggi (90\% dari hasil teoritik) dibandingkan dengan hidrolisis menggunakan asam encer, dan dengan demikian akan menghasilkan etanol yang lebih tinggi (Hamelinck, Hooijdonk \& faaij, 2005). Di dalam metode hidrolisa asam, biomassa lignoselulosa dipaparkan dengan asam pada suhu dan tekanan tertentu selama waktu tertentu. Yang akan menghasilkan monomer gula dari polimer sellulosa dan hemisellulosa (Taherzadeh, 2007). Kelemahan dari hidrolisa asam pekat adalah proses ini sangat korosif karena adanya pengenceran dan pemanasan asam. Proses ini juga membutuhkan biaya investasi yang mahal dan pemeliharaan yang tinggi (Taherzadeh dan Karimi, 2008). Karena itu hidrolisis ini biasanya menggunakan tanki khusus yang terbuat dari baja tahan karat atau tembaga yang dihubungkan dengan pipa saluran pemanas dan pipa saluran udara untuk mengatur tekanan dalam udara selulosa dari rumput dapat diubah menjadi etanol dengan proses hidrolisis asam dengan kadar tertentu. Proses hidrolisis selulosa harus dilakukan dengan asam pekat agar dapat menghasilkan glukosa (Sari, 2009). Rusaknya Kristal selulosa akan mempermudah terurainya selulosa menjadi glukosa. Selain itu, hemiselulosa turut terurai menjadi gula sederhana : glukosa, galaktosa, manosa, heksosa, pentose, xilosa dan arabinosa. Selanjutnya senyawasenyawa gula tersebut akan difermentasi oleh mikroorganisme menghasilkan etanol (Mosier et al, 2005). Pada penelitian Ni Ketut Sari (2009), menyatakan bahwa ketersediaan rumput gajah dapat diperoleh secara kontinyu dan melimpah, merupakan salah satu tanaman yang kurang dimanfaatkan. Tetapi rumput gajah mempunyai kadar selulosa, glukosa, pati yang dapat digunakan sebagai salah satu bahan penghasil ethanol. Kadar ethanol yang diperoleh dari kajian produksi bioethanol dari rumput gajah antara 23-28 \%, untuk meningkatkan kemurnian kadar ethanol dilakukan pemisahan menggunakan distilasi batch. Penelitian produksi bioethanol dari rumput gajah secara kimia bertujuan untuk mencari bahan baku alternatif bioethanol dan mengkaji proses hidrolisis asam dan fermentasi. Dalam penelitian produksi bioethanol dari rumput gajah secara kimia dilakukan proses hidrolisis pada kondisi tetap : suhu $30^{\circ} \mathrm{C}$, air 7 liter, waktu hidrolisis 1 jam dan kondisi berubah: berat rumput gajah 50, 100, 150, 200, 250, 300 (gram), volume larutan $\mathrm{HCl} \mathrm{10,20,30,} \mathrm{40,} 50$ (ml). Kemudian dilanjutkan proses fermentasi pada kondisi tetap: suhu $30{ }^{\circ} \mathrm{C}, \mathrm{pH} \mathrm{4,5}$; volume fermentasi $500 \mathrm{ml}$ dan kondisi berubah: waktu fermentasi 4, 5, 6, 7 dan 8 (hari), starter $8 \%, 10 \%, 12 \%$. Dari penelitian produksi bioethanol dari rumput gajah 
secara kimia diperoleh hasil, pada proses hidrolisis kadar glukosa yang terbaik $26,29 \%$, berat rumput gajah 200 gram. Pada proses fermentasi kondisi terbaik menggunakan starter Saccharomyces Cerevisiae $10 \%$ selama 6 hari, menghasilkan ethanol sebesar 27,71\% dan kadar glukosa sisa $8.09 \%$. Untuk memperoleh produk ethanol yang lebih murni dilakukan proses pemisahan lanjutan dengan distilasi batch, setelah dilakukan pemisahan lanjut diperoleh kadar ethanol (90-95) \%. Dari hasil yang diperoleh yaitu kadar ethanol (90-95)\%, rumput gajah dapat digunakan sebagai bahan baku alternatif pembuatan bioethanol. Penelitian lain oleh Hafni Indriati Nasution; Ratna Sari Dewi dan Primajogi Hasibuan (2016), melakukan penelitian pembuatan etanol dari rumput gajah dengan menggunakan hidrolisis asam dengan berat rumput gajah 28,5 gram dengan waktu hidrolisis 2 jam, volume katalis 30 tetes dan jumlah starter (Saccharomyces cerevisease) sebanyak $10 \%$ dan waktu fermentasi 2, 4, 6, 8 hari. Dalam penelitian ini didapat kadar optimum sebesar 20-30\% didapat pada waktu fermentasi 6 hari. Penelitian ini dilakukan oleh Setiawati , D.R., Sinaga, A.R., Dewi, T.K., (2013), ia menggunakan kulit pisang yang digunakan adalah kulit pisang yang telah dikeringkan dan dihidrolisis menggunakan $\mathrm{H}_{2} \mathrm{SO}_{4} 0,5 \mathrm{~N}$. hasil penelitian menunjukkan bahwa semakin lama fermentasi semakin banyak dihasilkan etanol sampai pada waktu tertentu dan semakin banyak ragi yang ditambahkan akan dihasilkan etanol semakin rendah. Pada variasi waktu fermentasi diperoleh waktu optimum fermentasi pada waktu 144 jam dengan kadar etanol $13,5406 \%$. Pada variasi penambahan berat ragi diperoleh kadar etanol 13,5353\% dengan kadar berat ragi 0,0624 gram.

\section{METODELOGI PENELITIAN}

Peralatan dan Bahan

Peralatan hidrolisis: Blender, cuter, ayakan, peralatan gelas, alat pemanas, thermometer, kondensor, batang pengaduk; Peralatan analisis: $\mathrm{pH}$ meter, peralatan fermentasi, fermentor (wadah fermentasi), selang, dan Peralatan Pemurnian: alat destilasi, Peralatan analisa: Pikometer. Rumput Gajah, Bakteri Saccharomyces Cerevisiae, $\mathrm{H}_{2} \mathrm{SO}_{4}, \mathrm{HCL}, \mathrm{NaOH}, \mathrm{Na}_{2} \mathrm{~S}_{2} \mathrm{O}_{3}$, KI, NPK dan Urea.

Rumput Gajah, Bakteri Saccharomyces Cerevisiae, $\mathrm{H}_{2} \mathrm{SO}_{4}, \mathrm{HCL}, \mathrm{NaOH}, \mathrm{Na}_{2} \mathrm{~S}_{2} \mathrm{O}_{3}, \mathrm{KI}, \mathrm{NPK}$ dan Urea.

\section{Rancangan Penelitian}

Variabel tetap adalah massa bahan baku (rumput gajah) sebesar 100 gram, volume fermentasi 1 liter, waktu hidrolisis, volume dan konsentrasi katalis 1,$5 ; 2 ; 2,5 ; 3$ dan 3,5 N. Variabel tidak tetap yaitu Konsentrasi katalis, waktu hidrolisis dan jumlah Saccharomyces Cerevisiae.

\section{Proses Pembuatan bioetanol}

\section{Alkaline Delignifikasi}

1. Rumput gajah dihaluskan menggunakan blender dan diayak.

2. Serbuk rumput gajah sebanyak 200 gr dan dimasukkan ke dalam erlenmeyer berukuran $1000 \mathrm{ml}$.

3. Tambahkan larutan $\mathrm{NaOH}(8,10,12,14$ dan $16 \%)$ dengan perbandingan bahan dan larutan $\mathrm{NaOH}$ sebesar 1:4 (b/v) untuk 200 gram rumput gajah kemudian diinkubasi dalam water bath pada suhu $121^{\circ} \mathrm{C}$ selama 1 jam.

4. Sampel disaring dan dicuci hingga $\mathrm{pH}$ netral kemudian dikeringkan dalam oven pada suhu $105^{\circ} \mathrm{C}$. 
5. Analisa kadar lignin selulosa dan hemiselulosa dengan metode Chesson Datta dan kadar lignin dengan metode kappa.

\section{Hidrolisa Asam $\mathrm{H}_{2} \mathrm{SO}_{4}$ dan $\mathrm{HCL}$}

1. Rumput gajah yang telah halus sebanyak 100 gram dihidrolisis dengan menambahkan aquadest 1 liter dan katalis $\mathrm{H}_{2} \mathrm{SO}_{4}$, $\mathrm{HCL}$ pada konsetrasi 1,$5 ; 2,0 ; 2,5 ; 3,0$ dan 3,5

2. Campuran tersebut kemudian kita hidrolisa pada temperatur $100^{\circ} \mathrm{C}$ dengan waktu untuk tiap variasi temperaturnya adalah 120, 150, 180, 210, 240 menit

\section{Fermentasi}

Hasil hidrolisis disaring dengan kertas saring, fitrat selanjutnya difermentasi dengan penambahan starter (Saccharomyces cerevisease) sebanyak $8 \%$ dari jumlah filtrat yang difermentasi, $\mathrm{pH}$ fermentasi 4 dan dilakukan penambahan Nutrisi NPK (16\% P), 0,4 gr/L dan Urea (46\% P) 0,5 gr/L dari volume hasil hidrolisis. Proses fermentasi dilakukan dalam keadaan anaerob dengan menutup rapat botol dan mengamati pada waktu (4 hari)

\section{Distilasi}

Pemurnian produk bioetanol dengan cara mendestilasi hasil fermentasi pada suhu $70-80{ }^{\circ} \mathrm{C}$ (suhu tetap dijaga) setelah volume larutan tinggal $10 \%$ destilasi dihentikan dan dianalisis kadar etanolnya.

\section{HASIL DAN PEMBAHASAN}

\section{Pengaruh Konsentrasi Alkaline Acid Delignifikasi Terhadap Kadar Lignin}

Rumput gajah adalah salah satu tanaman yang dianggap pengganggu yang mengandung selulosa dan hemiselulosa. Rumput gajah dapat dikonversi menjadi bioetanoldengan proses hidrolisis asam. Namun penggunaan asam pekat mengalami hambatan dalammerubah bahan menjadi bioetanol akibat adanya lignin yang melindungi selulosa dan hemiselulosa. Lignin mengurangi keefektifan hidrolisis asam pekat. Untuk mengatasi hal tersebut, maka perlu dilakukan perlakuan pendahuluan terhadap rumput gajah dengan tujuan merusak struktur lignin agar selulosa dan hemiselulosa bisa terlepas dan bereaksi sehingga bisa menghasilkan bioetanol. Proses yang biasa dilakukan untuk merusak struktur lignin adalah proses hidrolisis basa atau disebut proses delignifikasi (Sahare et al., 2012; Laopaiboon et al, 2009). Selulosa secara alami diikat oleh hemiselulosa dan dilindungi oleh lignin. Adanya senyawa pengikat lignin inilah yang menyebabkan bahan-bahan lignoselulosa sulit dihidrolisa (Badger dkk., 2002). Oleh karena itu, proses delignifikasi merupakan tahapan proses yang sangat penting yang dapat mempengaruhi jumlah kadar bioethanol yang didapat. Proses delignifikasi dilakukan untuk mengkondisikan bahan-bahan lignoselulosa baik dari segi struktur dan ukuran dengan memecah dan menghilangkan kandungan lignin (Sun Y.,Cheng, 2002).

Proses delignifikasi pada penelitian ini dilakukan dengan menggunakan variabel bebas berupa larutan $\mathrm{NaOH}$ dengan konsentrasi $(8,10,12,14,16) \%$ proses ini dengan temperatur sebesar $121^{\circ} \mathrm{C}$ dan dengan waktu delignifikasi selama 60 menit. Setelah dilakukan proses delignifikasi, kadar lignin dianalisa dengan metode kappa dan hasilnya dapat dilihat pada grafik berikut. 


\section{Proses Penelitian Pembuatan Bioetanol}

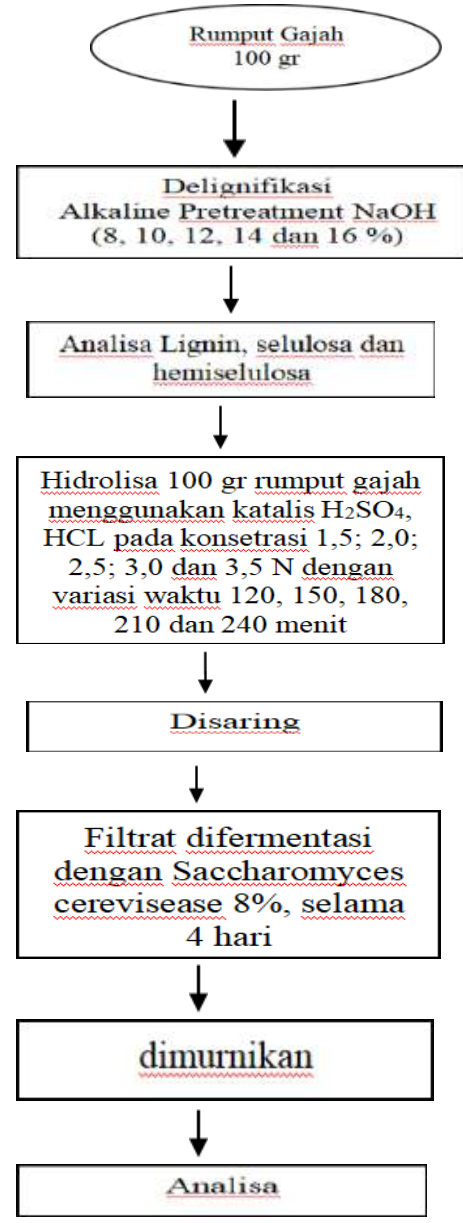

Gambar 3 Diagram Alir Pembuatan Bioetanol

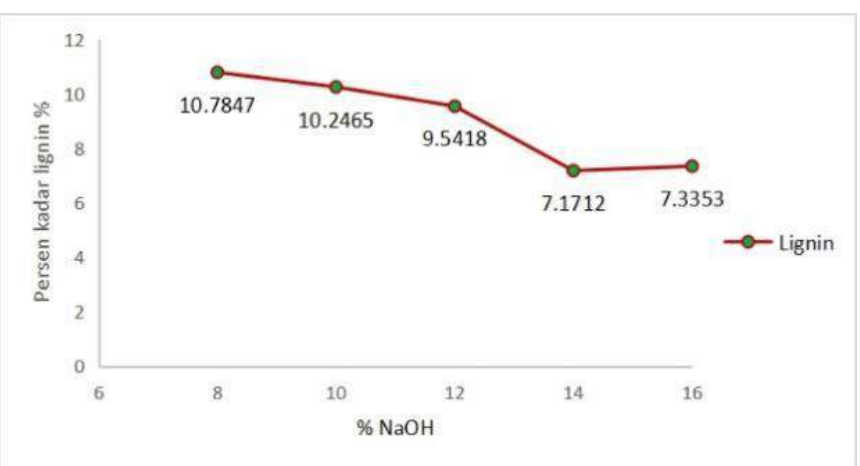

Gambar 4. Pengaruh konsentrasi alkaline delignifikasi terhadap penurunan kadar lignin

Dari gambar 3 dapat dilihat bahwa setelah dilakukan proses delignifikasi menggunakan basa kuat terjadi penurunan kadar lignin dari 10,7847\% menjadi 7,1712\% pada penggunaan $\mathrm{NaOH}$. Proses delignifikasi 
menggunakan basa kuat, semakin besar konsentrasi dari suatu larutan maka akan semakin banyak molekul dari larutan itu yang dapat memecah struktur lignin. Peningkatan konsentrasi $\mathrm{NaOH}$ semakin menurunkan kadar lignin dan meningkatkan kadar lignin terurai, yaitu pada konsentrasi $8 \%$ kadar lignin sebesar 10,7847\%, konsentrasi 10\% kadar lignin 10,2465\%, konsentrasi 12\% menghasilkan kadar lignin 9,5418\%, konsentrasi $14 \%$ menghasilkan kadar lignin 7,1712\% dan pada konsentrasi $16 \%$ delignifikasi rumput gajah menghasilkan kadar lignin sisa sebanyak 7,3353\%. Berdasarkan keterangan diatas dapat diketahui bahwa peningkatan kadar lignin terurai sejalan dengan peningkatan konsentrasi $\mathrm{NaOH}$. Kadar lignin terurai terus mengalami peningkatan hingga mencapai titik konstan pada konsentrasi $14 \%$ dan 16\%. Jadi, dapat disimpulkan bahwa konsentrasi $\mathrm{NaOH}$ yang menghasilkan kadar lignin paling sedikit pada konsentrasi $14 \%$.

Menurut Sahare et al. (2012) dalam Mardina et al. (2013). Pengurangan kadar lignin yang semakin besar menyebabkan semakin banyak selulosa yang reaktif untuk proses hidrolisis.

\section{Pengaruh Konsentrasi Alkaline Acid Delignifikasi Terhadap Kadar Selulosa Dan Hemiselulosa Pada Rumput Gajah}

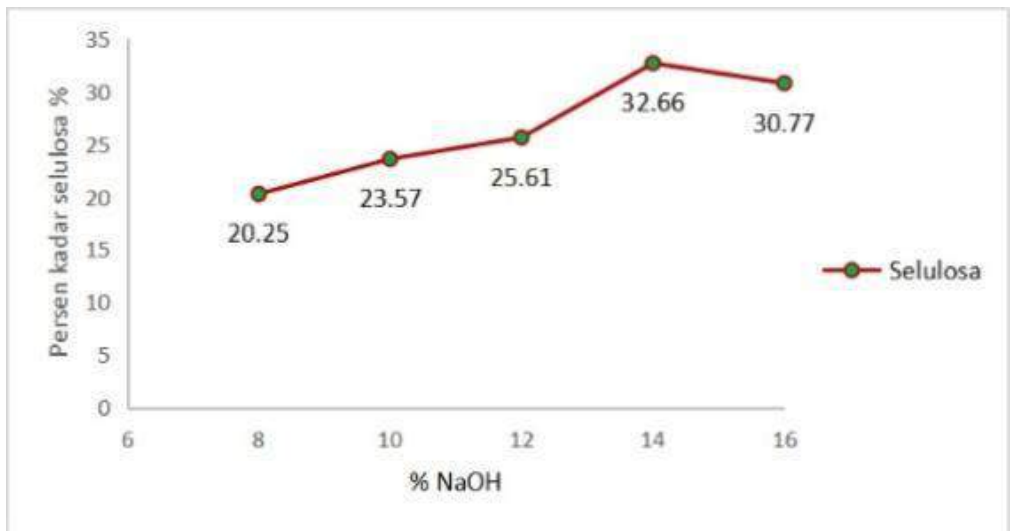

Gambar 5. Pengaruh konsentrasi alkaline delignifikasi terhadap kadar selulosa

Dari gambar 5 dapat dilihat bahwa setelah dilakukan alkaline delignifikasi maka kandungan selulosa akan meningkat mulai dari $20,25 \%$ hingga $32,66 \%$ pada alkaline delignifikasi. Peningkatan selulosa tertinggi terjadi pada konsentrasi $14 \%$ sebesar $32,66 \%$.

Pada saat dilakukan treatment kimia, komponen selulosa dan hemiselulosa didapatkan sebagai residu yang digunakan sebagai bahan untuk proses analisasedangkan lignin didapatkan sebagai filtrat yang terbuang. Sehinggadidapatkan komponen selulosa dan hemiselulosa yang meningkat dari kondisi sebelum treatment kimia. 


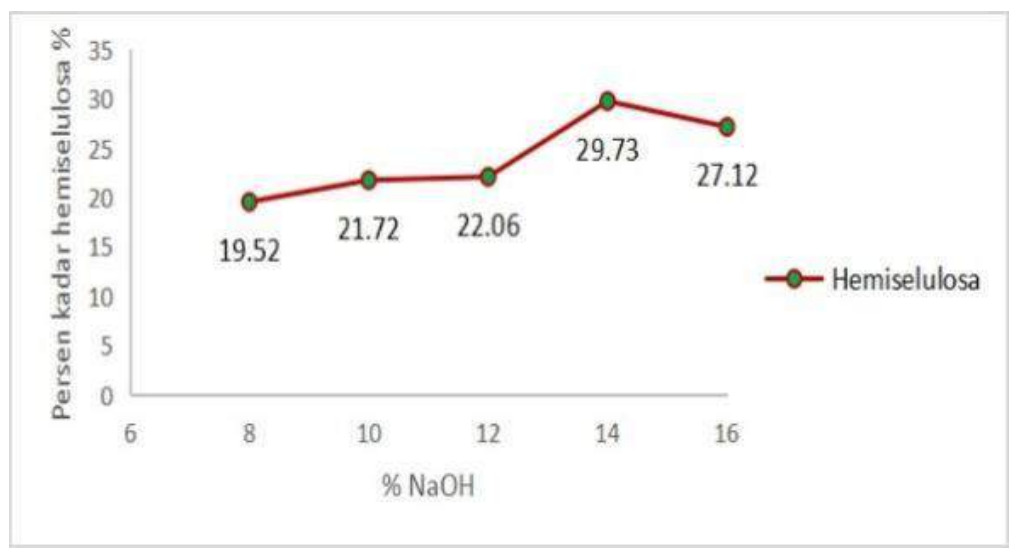

Gambar 6. Pengaruh konsentrasi alkaline delignifikasi terhadap kadar hemiselulosa

Dari gambar 6 dapat dilihat bahwa setelah dilakukan alkaline delignifikasi maka kandungan hemiselulosa akan meningkat mulai dari $19,52 \%$ hingga $29,73 \%$ pada alkaline delignifikasi. Peningkatan selulosa tertinggi terjadi pada konsentrasi $14 \%$ sebesar $29,73 \%$.

Dari gambar tersebut dapat disimpulkan bahwa setelah dilakukan proses delignifikasi menggunakan alkaline delignifikasi kadar hemiselulosa terus meningkat. Untuk dapat mengambil hemiselulosa dan selulosa dari rumput gajah dibutuhkan proses delignifikasi yang bertujuan untuk melepaskan kandungan lignin tanpa merusak kandungan selulosa dan hemiselulosa yang diambil dari proses tersebut.

\section{Pengaruh konsentrasi 1,5 $\mathrm{N} \mathrm{H}_{2} \mathrm{SO}_{4}$ dan waktu hidrolisis}

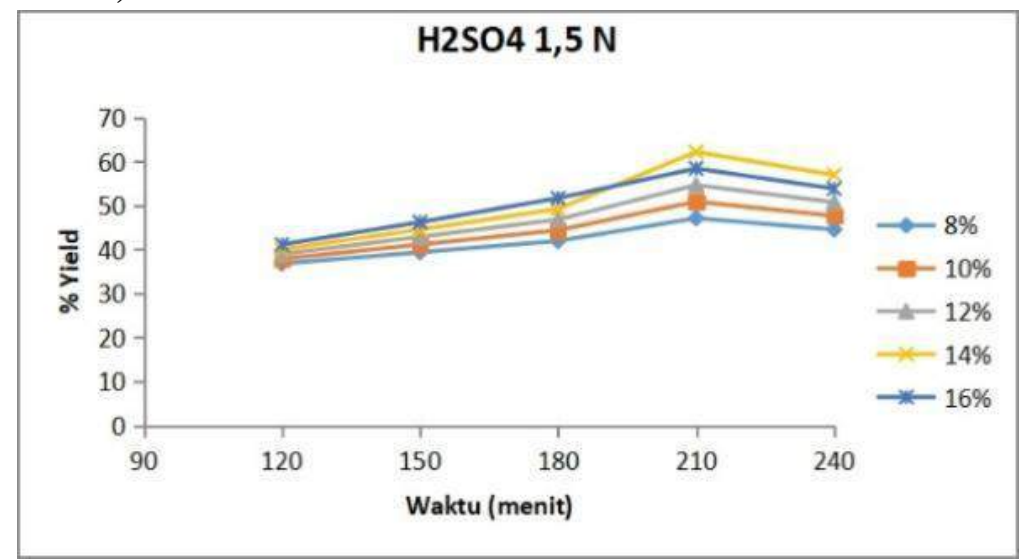

Gambar 7. Grafik Pengaruh konsentrasi 1,5 $\mathrm{N} \mathrm{H}_{2} \mathrm{SO}_{4}$ dan waktu hidrolisis terhadap kadar yield yang dihasilkan dengan konsentrasi alkaline delignifikasi

Penelitian ini dilakukan dengan memvariasikan waktu hidrolisis dan katalis asam sulfat yang digunakan untuk mengetahui pengaruh dari waktu. konsentrasi katalis dan waktu fermentasi selama 4 hari terhadap hasil analisis kadar \% yield yang menggunakan basa kuat saat proses delignifikasi.

Gambar 7. menunjukkan konsentrasi delignifikasi $\mathrm{NaOH}$ terhadap analisis kadar \% yield. Pada gambar terlihat jelas bahwa semakin lama waktu pada proses hidrolisis maka semakin besar pula kadar \% yield yang dihasilkan. Kadar \% yield paling besar terjadi pada sampel dengan delignifikasi $\mathrm{NaOH} 14 \%$ dengan waktu hidrolisis 210 menit yaitu 62,2198\%. Hal ini terjadi karena pada sampel dengan 
delignifikasi $\mathrm{NaOH} 16 \%$ terjadinya pengurangan lignin paling besar mengakibatkan kadar lignin yang tersisa pada sampel paling sedikit.

\section{Pengaruh konsentrasi $2 \mathrm{~N} \mathrm{H}_{2} \mathrm{SO}_{4}$ dan waktu hidrolisis}

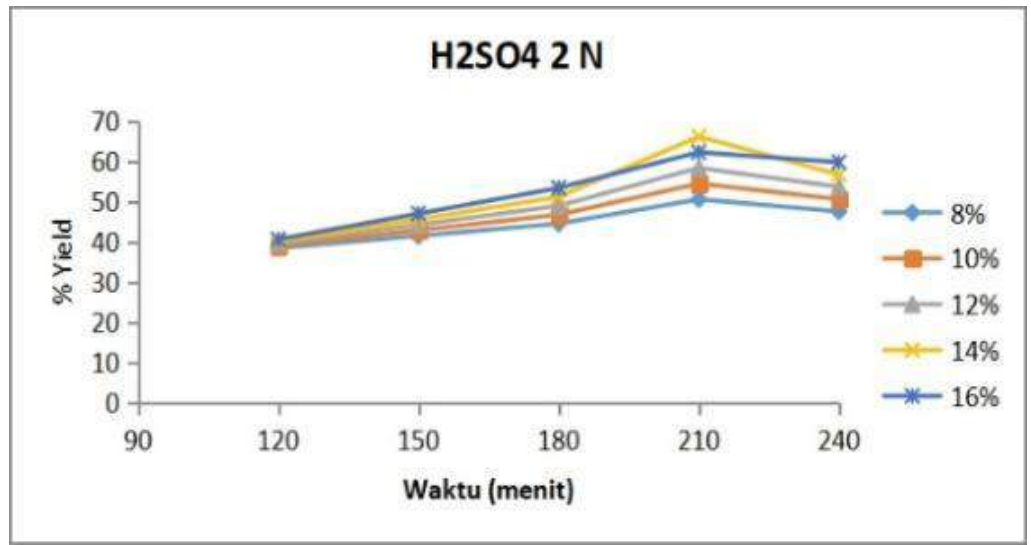

Gambar 8. Grafik Pengaruh konsentrasi $2 \mathrm{~N} \mathrm{H}_{2} \mathrm{SO}_{4}$ dan waktu hidrolisis terhadap kadar yield yang dihasilkan dengan konsentrasi alkaline delignifikasi

Gambar 8. menunjukkan hasil dari konsentrasi delignifikasi $\mathrm{NaOH}$ terhadap analisis kadar \% yield. Pada gambar diatas terlihat jelas bahwa semakin lama waktu pada proses hidrolisis maka hasil kadar \% yield yang dihasilkan semakin besar. Hasil kadar \% yield paling besar terjadi pada sampel dengan delignifikasi $\mathrm{NaOH}$ 14\% dengan waktu hidrolisis 210 menit yaitu 66,1538\%.

Pengaruh konsentrasi 2,5 $\mathrm{N} \mathrm{H}_{2} \mathrm{SO}_{4}$ dan waktu hidrolisis

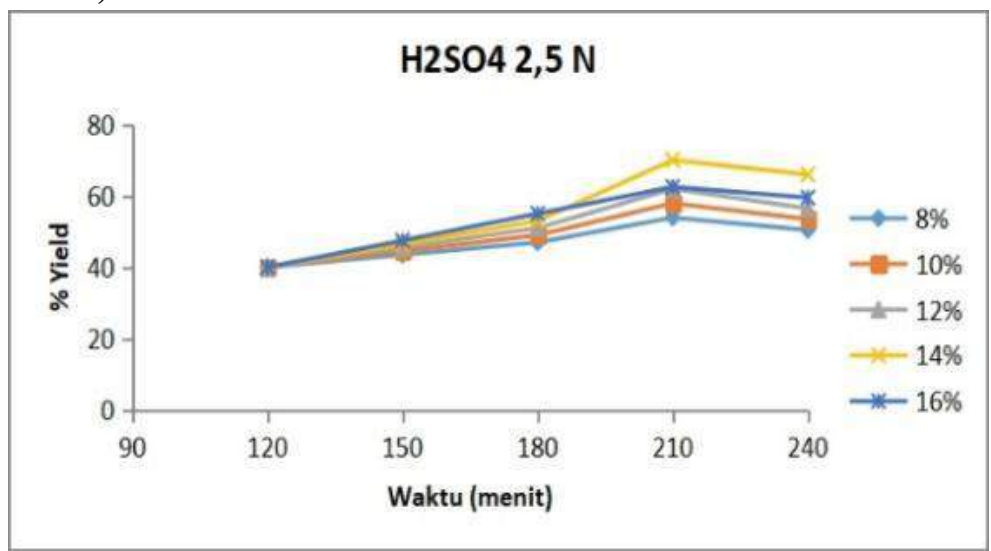

Gambar 9. Grafik Pengaruh konsentrasi 2,5 $\mathrm{N} \mathrm{H}_{2} \mathrm{SO}_{4}$ dan waktu hidrolisis terhadap kadar yield yang dihasilkan dengan konsentrasi alkaline delignifikasi

Pada gambar 9, grafik hasil \% yield bioetanol menunjukkan hasil terbaik pada sampel delignifikasi $\mathrm{NaOH}$ dengan konsetrasi 14\% dalam waktu hidrolisis 210 menit yaitu 70,0879\%. 


\section{Pengaruh konsentrasi $3 \mathrm{~N} \mathrm{H}_{2} \mathrm{SO}_{4}$ dan waktu hidrolisis}

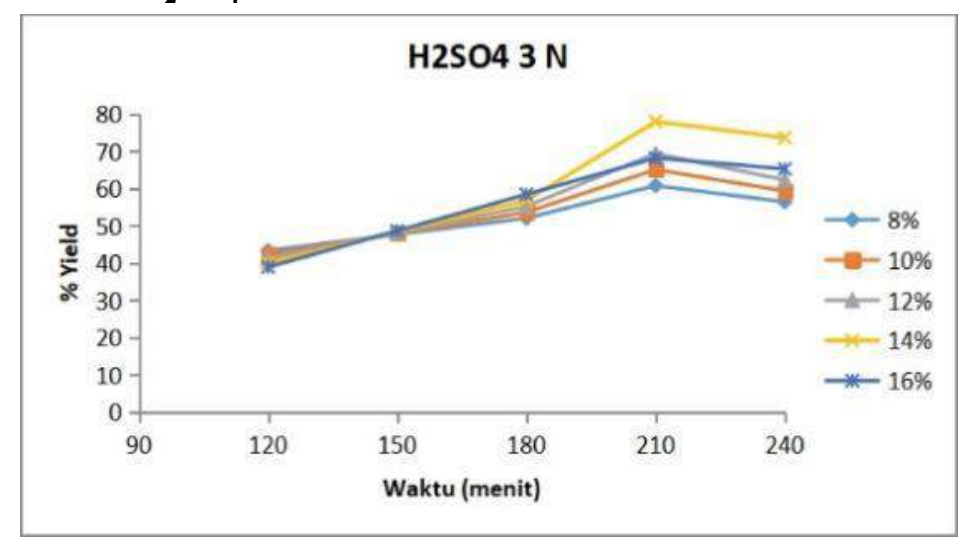

Gambar 10. Grafik Pengaruh konsentrasi $3 \mathrm{~N} \mathrm{H}_{2} \mathrm{SO}_{4}$ dan waktu hidrolisis terhadap kadar yield yang dihasilkan dengan konsentrasi alkaline delignifikasi

Gambar 10. menunjukkan konsentrasi delignifikasi $\mathrm{NaOH}$ terhadap analisis kadar \% yield. Pada gambar grafik konsetrasi asam sulfat $3 \mathrm{~N}$ terlihat jelas bahwa semakin lama waktu pada proses hidrolisis maka semakin besar pula kadar \% yield yang dihasilkan. Kadar \% yield yang dihasilkan paling besar terjadi pada sampel delignifikasi dengan konsentrasi $\mathrm{NaOH} 14 \%$ pada waktu hidrolisis 210 menit yaitu $77,9560 \%$. Hal ini terjadi karena pada sampel dengan delignifikasi $\mathrm{NaOH} 16 \%$ terjadinya pengurangan lignin paling besar mengakibatkan kadar lignin yang tersisa pada sampel paling sedikit.

\section{Pengaruh konsentrasi 3,5 $\mathrm{N} \mathrm{H}_{2} \mathrm{SO}_{4}$ dan waktu hidrolisis}

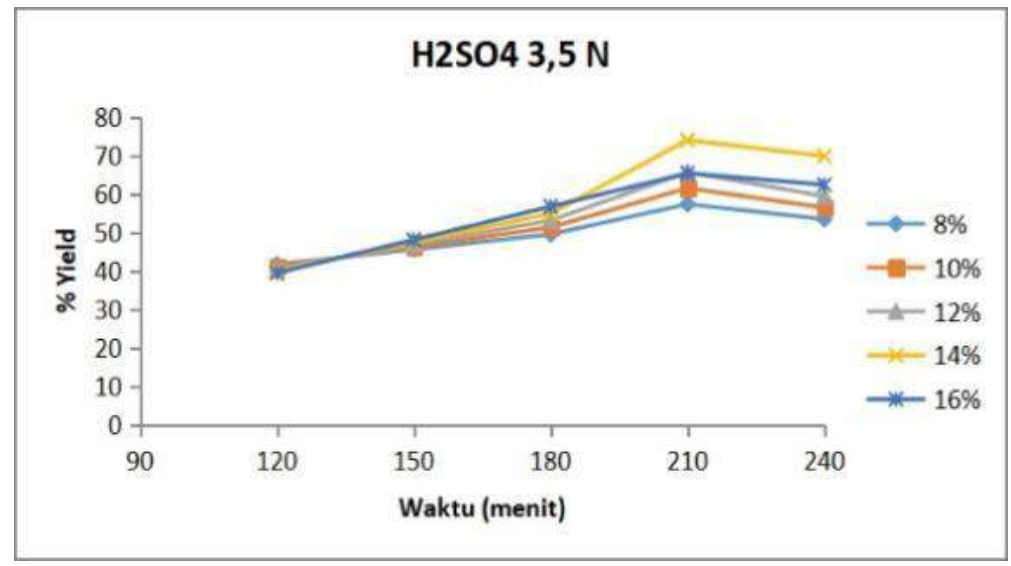

Gambar 11. Grafik Pengaruh konsentrasi 3,5 $\mathrm{N} \mathrm{H}_{2} \mathrm{SO}_{4}$ dan waktu hidrolisis terhadap kadar yield yang dihasilkan dengan konsentrasi alkaline delignifikasi

Gambar 11. menunjukkan hasil \% yield pada konsentrasi delignifikasi $\mathrm{NaOH}$ konsentrasi $14 \%$ pada waktu hidrolisis 210 menit yaitu 74,0220\% yield bioetanol. Pada gambar grafik konsetrasi asam sulfat 3,5 $\mathrm{N}$ terlihat jelas bahwa semakin lama waktu pada proses hidrolisis maka semakin besar pula kadar \% yield yang dihasilkan. Dari 10 grafik diatas, dapat disimpulkan bahwa kadar \% yield bioetanol yang dihasilkan pada sampel delignifikasi $\mathrm{NaOH}$ 14\% dengan waktu hidrolisis 210 menit pada konsentrasi $\mathrm{H}_{2} \mathrm{SO}_{4} 3 \mathrm{~N}$ adalah 77,9560\% yield dan kadar \% yield yang paling sedikit dihasilkan pada sampel delignifikasi $\mathrm{NaOH} 8 \%$ dengan waktu hidrolisis 120 menit pada konsentrasi $\mathrm{H}_{2} \mathrm{SO}_{4} 1,5 \mathrm{~N}$ adalah 
$36,8132 \%$. Jadi semakin besar konsentrasi larutan asam sulfat dan waktu yang digunakan ketika proses hidrolisis maka semakin besar pula kadar \% yield bioetanol yang dihasilkan.

Secara teori asam kuat adalah asam yang terionisasi secara sempurna dalam air dan menghasilkan suatu proton $(\mathrm{H}+)$ yang ditransferkan ke dalam molekul air. Proton dari asam akan berinteraksi cepat dengan oksigen pada ikatan glikosida yang menghubungkan antar gula. Menurut Fengel dan Wagener (1995) langkah ini diikuti dengan pemecahan yang lambat dari ikatan C-O menghasilkan zat antara kation karbonium siklis. Akhirnya kation karbonium mulai mengadisi molekul air dengan cepat, membentuk hasil akhir (glukosa) yang stabil dan melepaskan proton.

\section{Pengaruh konsentrasi HCL 1,5 N dan waktu hidrolisis}

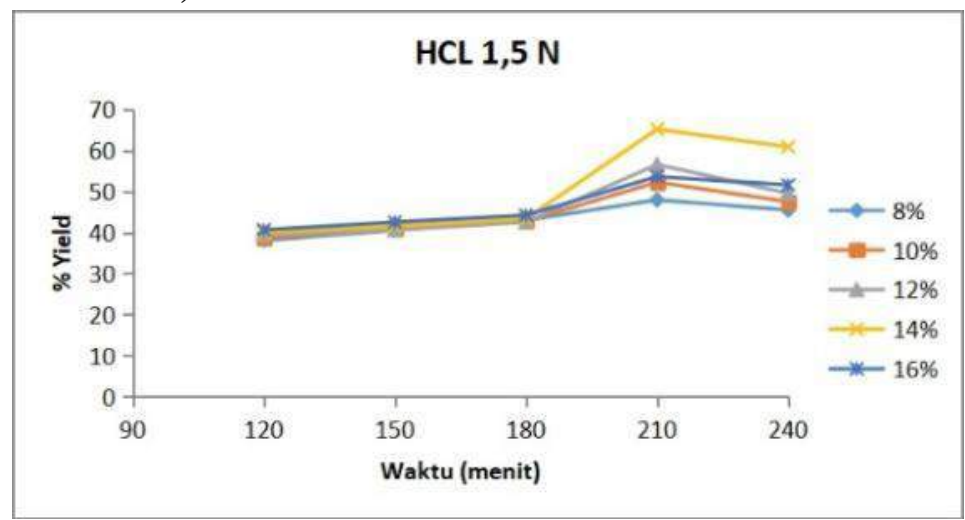

Gambar 12. Grafik Pengaruh konsentrasi 1,5 N HCL dan waktu hidrolisis terhadap kadar yield yang dihasilkan dengan konsentrasi alkaline delignifikasi

Penelitian ini dilakukan dengan memvariasikan waktu hidrolisis dan katalis HCL yang digunakan untuk mengetahui pengaruh dari waktu, konsentrasi katalis dan waktu fermentasi selama 4 hari terhadap hasil analisis kadar \% yield yang menggunakan basa kuat saat proses delignifikasi. Gambar 12. menunjukkan konsentrasi delignifikasi $\mathrm{NaOH}$ terhadap analisis kadar \% yield. Pada gambar terlihat jelas bahwa semakin lama waktu pada proses hidrolisis dan semakin besar konsentrasi pada proses delignifikasi $\mathrm{NaOH}$ maka semakin besar pula kadar \% yield yang dihasilkan. Kadar \% yield bioetanol paling besar terjadi pada sampel dengan delignifikasi $\mathrm{NaOH} 14 \%$ pada waktu hidrolisis 210 menit yaitu 65,1627\%.

\section{Pengaruh konsentrasi HCL 2 N dan waktu hidrolisis}

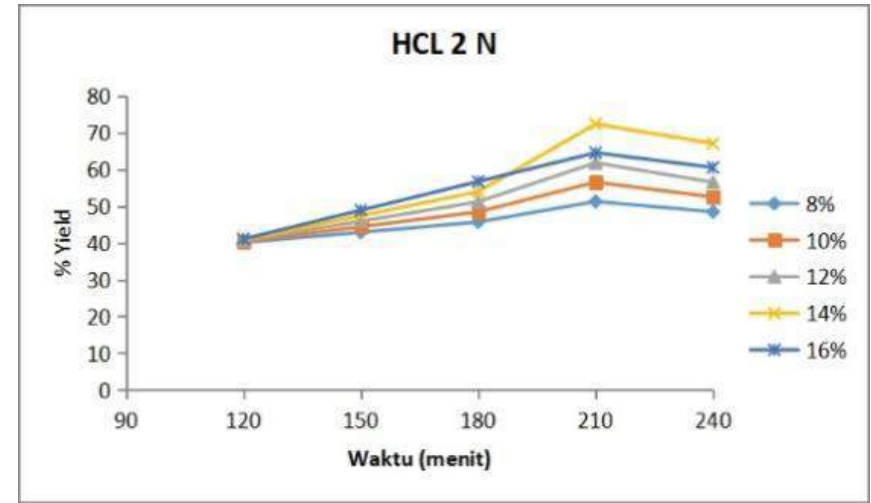

Gambar 13. Grafik Pengaruh konsentrasi 2 N HCL dan waktu hidrolisis terhadap kadar yield yang dihasilkan dengan konsentrasi alkaline delignifikasi 
Gambar 13. menunjukkan hasil Kadar \% yield bioetanol paling besar terjadi pada sampel dengan delignifikasi $\mathrm{NaOH} 14 \%$ pada waktu hidrolisis 210 menit yaitu 72,3210\%. Pada gambar terlihat jelas bahwa semakin lama waktu pada proses hidrolisis dan semakin besar konsentrasi pada proses delignifikasi $\mathrm{NaOH}$ maka semakin besar pula kadar \% yield yang dihasilkan.

\section{Pengaruh konsentrasi HCL 2,5 N dan waktu hidrolisis}

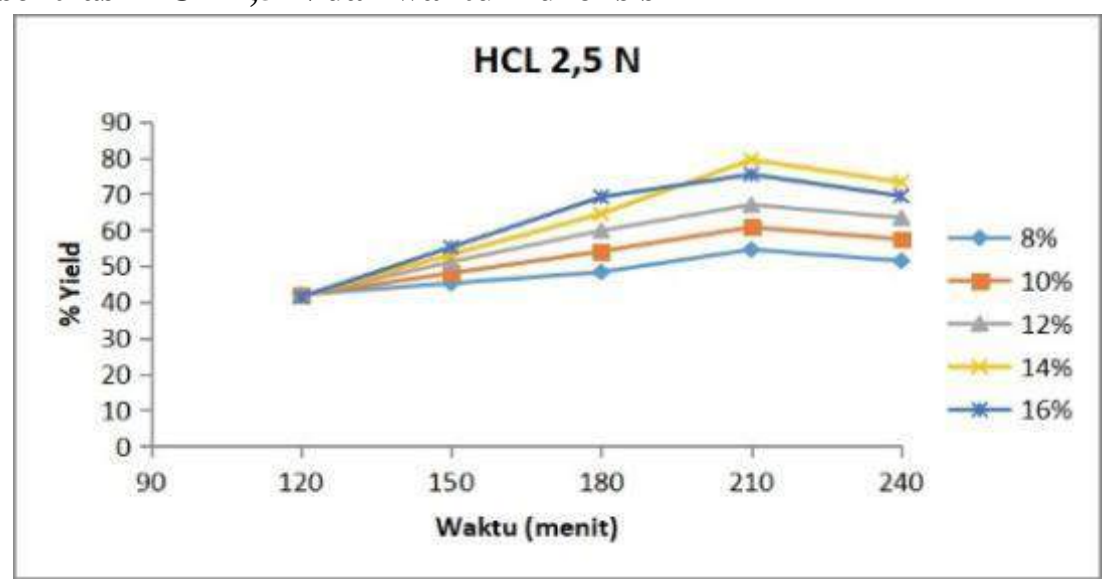

Gambar 14. Grafik Pengaruh konsentrasi 2,5 N HCL dan waktu hidrolisis terhadap kadar yield yang dihasilkan dengan konsentrasi alkaline delignifikasi

Dari gambar 14. Kadar \% yield yang dihasilkan paling besar terjadi pada sampel delignifikasi dengan konsentrasi $\mathrm{NaOH}$ 14\% pada waktu hidrolisis 210 menit yaitu 79,4794\%. Pada gambar terlihat jelas bahwa semakin lama waktu pada proses hidrolisis dan semakin besar konsentrasi pada proses delignifikasi $\mathrm{NaOH}$ maka semakin besar pula kadar \% yield yang dihasilkan. Namun pada hal ini terjadi penurunan pada sampel dengan delignifikasi $\mathrm{NaOH} 16 \%$ karena terjadinya pengurangan lignin paling besar mengakibatkan kadar lignin yang tersisa pada sampel paling sedikit.

\section{Pengaruh konsentrasi HCL 3 N dan waktu hidrolisis}

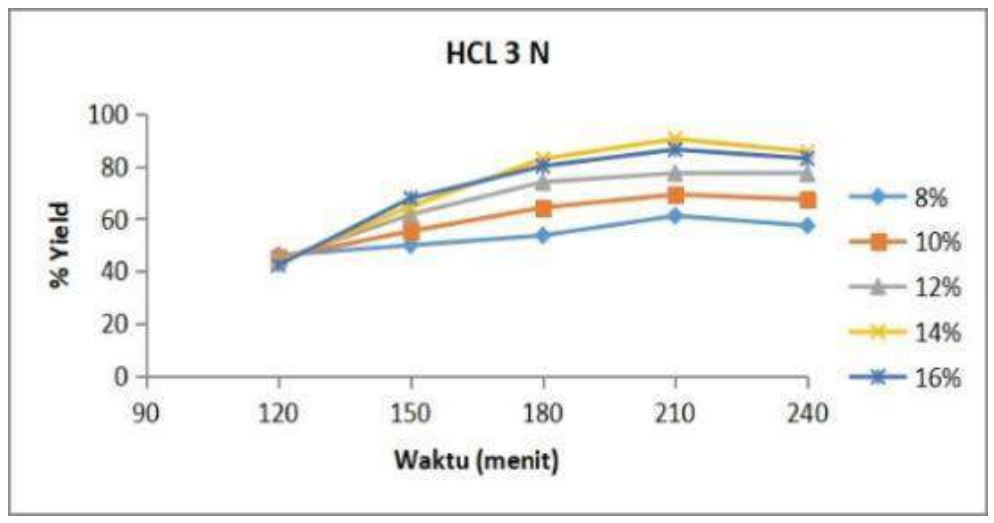

Gambar 15. Grafik Pengaruh konsentrasi 3 N HCL dan waktu hidrolisis terhadap kadar yield yang dihasilkan dengan konsentrasi alkaline delignifikasi 
Gambar 15. menunjukkan konsentrasi delignifikasi $\mathrm{NaOH}$ terhadap analisis kadar \% yield. Pada gambar grafik konsetrasi HCL $3 \mathrm{~N}$ terlihat jelas bahwa semakin lama waktu pada proses hidrolisis maka semakin besar pula kadar \% yield yang dihasilkan. Kadar \% yield yang dihasilkan paling besar terjadi pada sampel delignifikasi dengan konsentrasi $\mathrm{NaOH} 14 \%$ pada waktu hidrolisis 210 menit dengan konsentrasi HCL $3 \mathrm{~N}$ yaitu 90,5423\%. Hal ini terjadi karena pada sampel dengan delignifikasi $\mathrm{NaOH}$ $16 \%$ terjadinya pengurangan lignin paling besar mengakibatkan kadar lignin yang tersisa pada sampel paling sedikit.

\section{Pengaruh konsentrasi 3,5 N HCL dan waktu hidrolisis}

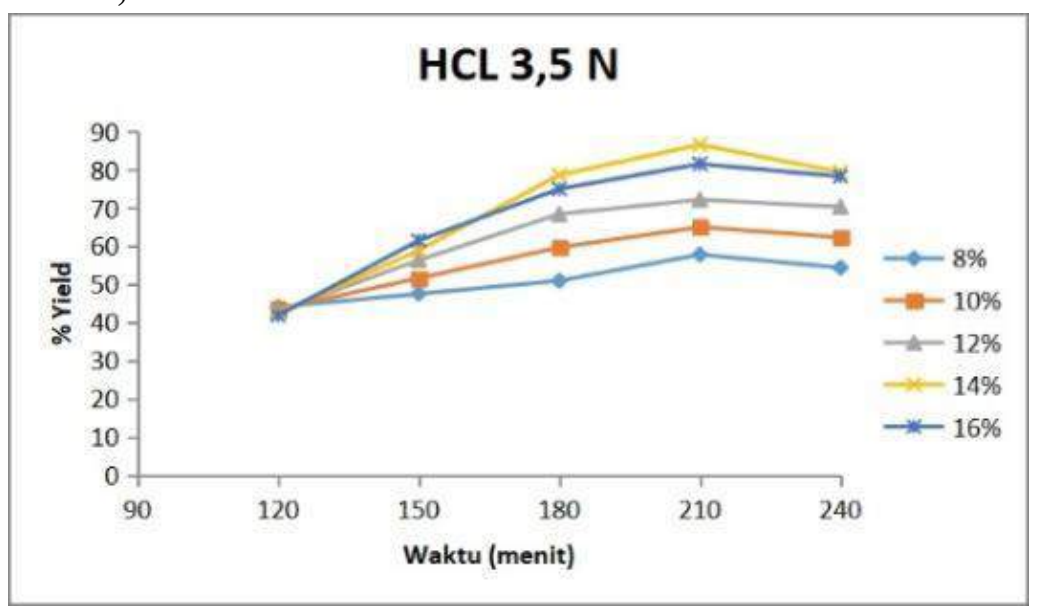

Gambar 16. Grafik Pengaruh konsentrasi 3,5 N HCL dan waktu hidrolisis terhadap kadar yield yang dihasilkan dengan konsentrasi alkaline delignifikasi

Gambar 16. menunjukkan hasil Kadar \% yield bioetanol paling besar terjadi pada sampel dengan delignifikasi $\mathrm{NaOH}$ 14\% pada waktu hidrolisis 210 menit dengan konsentrasi HCL 3,5 N yaitu 86,6377\%. Pada gambar terlihat jelas bahwa semakin lama waktu pada proses hidrolisis dan semakin besar konsentrasi pada proses delignifikasi $\mathrm{NaOH}$ maka semakin besar pula kadar \% yield yang dihasilkan Kesimpulan dari 5 grafik diatas, dapat disimpulkan bahwa kadar \% yield bioetanol yang dihasilkan pada sampel delignifikasi $\mathrm{NaOH}$ konsentrasi $14 \%$ dengan waktu hidrolisis 210 menit pada konsentrasi HCL $3 \mathrm{~N}$ adalah 90,5423\% yield dan kadar \% yield yang paling sedikit dihasilkan pada sampel delignifikasi $\mathrm{NaOH} 8 \%$ dengan waktu hidrolisis 120 menit pada konsentrasi HCL 1,5 N adalah 38,0694\%. Jadi semakin besar konsentrasi larutan HCL dan waktu yang digunakan ketika proses hidrolisis maka semakin besar pula kadar \% yield bioetanol yang dihasilkan.

Secara teori asam kuat adalah asam yang terionisasi secara sempurna dalam air dan menghasilkan suatu proton $(\mathrm{H}+)$ yang ditransferkan ke dalam molekul air. Proton dari asam akan berinteraksi cepat dengan oksigen pada ikatan glikosida yang menghubungkan antar gula. Menurut Fengel dan Wagener (1995) langkah ini diikuti dengan pemecahan yang lambat dari ikatan C-O menghasilkan zat antara kation karbonium siklis. Akhirnya kation karbonium mulai mengadisi molekul air dengan cepat, membentuk hasil akhir (glukosa) yang stabil dan melepaskan proton. 


\section{KESIMPULAN}

Penurunan kadar lignin paling tinggi ditunjukkan pada pretreatment menggunakan basa kuat yaitu $\mathrm{NaOH}$ dengan konsentrasi tertinggi (14\%) penurunan mulai dari $10,7847 \%$ menjadi $7,1712 \%$. Persen kandungan selulosa optimum sebanyak $32,66 \%$ dan hemiselulosa optimum sebanyak $29,73 \%$ pada konsentrasi $\mathrm{NaOH} 14 \%$. Hasil didapat melalui proses delignifikasi menggunakan basa kuat $(\mathrm{NaOH})$. kadar \% yield bioetanol pada sampel delignifikasi $\mathrm{NaOH}$ konsentrasi $14 \%$ dengan waktu hidrolisis 210 menit dengan menambahkan $\mathrm{H}_{2} \mathrm{SO}_{4}$ konsentrasi $3 \mathrm{~N}$ pada proses hidrolisis adalah 77,9560\% yield. Hasil kadar \% yield bioetanol pada sampel delignifikasi $\mathrm{NaOH}$ konsentrasi $14 \%$ dengan waktu hidrolisis 210 menit pada konsentrasi HCL $3 \mathrm{~N}$ adalah 90,5423\% yield. Hasil terbaik yang didapat dari penelitian ini yaitu pada sampel delignifikasi $\mathrm{NaOH}$ konsentrasi 14\%, waktu hidrolisis terbaik 210 menit dengan menggunakan penambahan katalis asam kuat HCL pada konsentrasi $3 \mathrm{~N}$.

\section{DAFTAR PUSTAKA}

Asyeni, Tamzil. 2017. Pemanfaatan Sabut Kelapa Menjadi Bioetanol dengan Proses Delignifikasi AcidPretreatment. Jurnal Teknik Kimia No 4, Vol 23

Badger, P.C. 2002. Ethanol from cellulose: A general review. Janick and A. Whipkey (Ed.). Trends in New Crops and New Uses. ASHS Press, Alexandria, VA: 17-21.

Berdasarkan Lembar Data Keselamatan Bahan Menurut Peraturan UE No 1907/2006, revisi tanggal 03.04.2018

Djojonegoro,W., (2005), Pemanfaatan BioEtanol sebagai Bahan Bakar Kendaraan Berbahan Bakar Premium http://www.renewableenergypartners.o rg/ethanol.html

Erlita yuni. 2016. Upsus siwab mendongkel populasi sapi. Dinas peternakan dan kesehatan hewan provinsi sumatera barat. http://www.sumbarprov.go.id/details/news/9178

Fengel, D. \& Wegener, G. 1995. Kimia Kayu, Reaksi Ultrastruktur: Terjemahan Hardjono, S. UGM Press, Yogyakarta.

Hafni Indriati Nasution; Ratna Sari Dewi, Primajogi Hasibuan 2016, Pembuatan Etanol dari Rumput Gajah (Pennisetum purpureum schumach) Menggunakan Metode Hidrolisis Asam dan fermentasi Saccharomyces cerevsiae, Jurnal pendidikan kimia, ISSN:2085-3653, Vol. 8, No. 2, Agustus 2016, 144-151

Hendriks, A.T. and Zeeman, G. (2009) Pretreatments to Enhance the Digestibility of Lignocellulosic Biomass. Bioresource Technology, 100, 10-18.

Hamelinck, C.N., Van Hooijdonk, G. and Faaij, A.P.C. (2005) Ethanol from Lignocellulosic Biomass: Techno-Economic Performance in Short-, Middleand Long Term. Biomass and Bioenergy, 28, 384-410.

Isroi, dkk., (2013), Effect of Manganese and Copper on Biological Pretreaatment of Oil Palm Empty Fruit Bunches by Pleurotus Floridanus LIPIMC99

Kumar P, Barrett DM, Delwiche MJ, Stroeve P. 2009. Methods for pretreatment of lignocellulosic biomass for efficient hydrolysis and biofuel production. Ind. Eng. Chem. Res. 48, 3713-3729.

Laopaiboon, P, Thani, A., Leelavatcharamas, V., dan Laopaiboon, L., 2009. Acid hydrolysis of sugarcane bagasse for lactic acid production. Bioresource Technology. 101(3), 1036-1043 
Mosier, N., et al. 2005. Features of Promising Technologies for Pretreatment of Lignocellulosic Biomass. Bioresource Technology 96(2005): 673-686.

Mardina. P, Adelina I. Talalangi, Jhon F. M. Sitinjak, Andri Nugroho , M. Reza Fahrizal, 2013, Pengaruh proses delignifikasi pada produksi glukosa dari tongkol jagung dengan hidrolisis asam encer, jurnal Konversi, Volume 2 No. 2, Oktober 2013, hal 17-23

Oktavianus, F., Sigiro, R.M., Bustan, M.D., (2013), Pembuatan Bioetanol Dari Batang Jarak Menggunakan Metode Hidrolisa Dengan Katalis Asam Sulfat, Jurnal Teknik Kimia

Retno Dyah dan Nuri Wasir. 2011. Pembuatan Bioetanol dari Kulit Pisang. Prosiding Seminar Nasional Teknik Kimia “Kejuangan” ISSN 1693 - 4393 Pengembangan Teknologi Kimia untuk Pengolahan Sumber Daya Alam Indonesia, Yogyakarta.

Rukmana, Rahmat dan Yudirachman, Herdi. 2015. Untung Selangit dari Agribisnis Teh. Yogyakarta: Lily Publisher.

Rukmana, R., (2005), Budi Daya Rumput Unggul Hijauan Pakan Ternak, Penerbit Kanisius, Yogyakarta

Sun Y., Cheng J. 2002. Hydrolysis of Lignocellulosic Materials for Ethanol Production: A Review. Bioresource Technology.

Sahare, P., Singh, R., Laxman, S., dan Rao, M., 2012. Effect of alkali pretreatment on the structural properties and enzymatic hydrolysis of corn cob. Applied biochemistry and biotechnology. 168(7), 1806-1819.

Sari, N. K. 2009. Produksi Bioethanol dari Rumput Gajah secara Kimia. JTKI Vol. 4(1), p. 265-273.

Setiawati , D.R., Sinaga, A.R., Dewi, T.K., (2013), Proses Pembuatan Bioetanol dari Kulit Pisang Kepok, Jurnal Teknik Kimia

Taherzadeh, Mohammad J. 2007. Acid-Based Hydrolysis Processes for Ethanol from Lignocellulosic Materials. Bio Resources 2(3), 472-499.

Taherzadeh MJ dan Karimi K. 2008. Pretreatment of lignocellulosic wastes to improve ethanol and biogas production: A Review. Int. J. Mol. Sci. 9: 1621-1651. 